\title{
A NEW SPECIES OF CLOACITREMA (DIGENEA, PHILOPHTHALMIDAE) FROM GREATER FLAMINGO (PHOENICOPTERUS ROSEUS) WITH REMARKS ON THE GENERA CLOACITREMA AND PYGORCHIS
}

\author{
R. K. Schuster \\ Central Veterinary Research Laboratory, \\ Dubai, PO Box 597, United Arab Emirates \\ E-mail: moniezia@zedat.fu-berlin.de
}

\begin{abstract}
A New Species of Cloacitrema (Digenea, Philophthalmidae) from Greater Flamingo (Phoenicopterus roseus) with Remarks on the Genera Cloacitrema and Pygorchis. Schuster R. K. - Cloacitrema dubaiensis Schuster, sp. n. is described from four adult specimens found in the cloaca of greater flamingos in Dubai, UAE. It is the first Cloacitrema species found in the Afrotropic ecozone. The new species is medium-sized and slim, with the ventral sucker in equatorial position and the uterus that extends laterally to intestinal caeca. It has oval, unlobed, touching each other testes in parallel to slightly oblique position. C. dubaiensis resembles $C$. narrabeenensis but differs in body shape, position of acetabulum, size of the seminal vesicle and number of vitelline follicles and their extension lateral to caeca.
\end{abstract}

Key words: Cloacitrema, new species, Digenea, Philophthalmidae, Phoenicopterus roseus, the UAE.

\begin{abstract}
Новый вид рода Cloacitrema (Digenea, Philophthalmidae) из обыкновенного фламинго (Phoenicopterus roseus) с замечаниями о родах Cloacitrema и Pygorchis. Шустер P. К. - Cloacitrema dubaiensis Schuster, sp. n. описывается по четырём взрослым экземплярам, обнаруженным в клоаке обыкновенных фламинго в Дубае (ОАЭ). Это первый вид Cloacitrema, найденный в Афротропическом регионе. Новый вид отличается средними размерами, удлинённой формой тела, экваториальным положением вентральной присоски и маткой, простирающейся латерально до ветвей кишечника. Семенники овальные, не разделенные на лопасти, касающиеся друг друга, лежащие параллельно, или слегка диагонально. Вид C. dubaiensis подобен C. narrabeenensis, но отличается от него формой тела, положением брюшной присоски, размером семенного пузырька, количеством желточников и их протяженностью латерально до уровня кишечных стволов.
\end{abstract}

Ключевы е слова: Cloacitrema, новый вид, Digenea, Philophthalmidae, Phoenicopterus roseus, OАЭ.

Introduction

The subfamily Cloacitrematinae Yamaguti, 1958 of the family Philophthalmidae Looss, 1899 consists of two morphologically similar genera Cloacitrema Yamaguti, 1935 and Pygorchis, Looss, 1899 representatives of which inhabit the cloaca of birds. The genus Cloacitrema with the type species C. ovatum Yamaguti, 1934 from Bucephala clangula (Linnaeus, 1758) in Japan was founded by Yamaguti (1935). So far, seven further species have been described. These are C. michiganensis McIntosh, 1938 from Actitis macularia (Linneus, 1758) and Himantopus mexicanus (Müller, 1776) in Michigan and Florida (USA), C. oswaldoi Travassos, 1940 from Nyctianassa violacea (Linneus, 1758) in Brazil, C. deltoidea Mamaev, 1959 from Tringa incana (Gmelin, 1789) in Yakutia (Russia), C. marilae Cimbaluk et Leonov 1963 from Aythya marila (Linneus, 1761) in Kamchatka (Russia), C. pharyngeata Belopol'skaja, 1963 from Tringa glareola (Linneus, 1758) in the Far East of Russia, C. narrabeenensis Howell et Bearup (1967) from Croicocephalus novaehollandiae (Stevens, 1826) in Australia and C. philippinum Velasquez, 1969 in Gallus domesticus (Linneus, 1758) and Anas platyrhynchos (Linneus, 1758). The closely related genus Pygorchis Looss, 1899 consists of P. affixus Looss, 1899 from Corvus cornix Linneus, 1758, Falco tinnunculus Linneus, 1758, Circus aerogenosus (Linneus, 1758) in Egypt, P. alacolensis Žatkanbaeva, 1967 from Croicocephalus ridibundus (Linneus, 1758), Hydroprogne caspia Kaup, 1829, Sternea hirundo Linneus, 1758 in Kazakhstan and P. americanus Dronen, 1985 from Ajaia ajaja Linneus, 1758 in Texas (USA).

The aim of this paper is to describe a new Cloacitrema species found in Phoenicopterus roseus Pallas, 1811. 


\section{Material and methods}

Trematodes attached to the cloaca were found in four out of five greater flamingos originating from Ras al Khor wildlife sanctuary situated at the terminal point of the creek of Dubai, UAE $\left(25^{\circ} 11^{\prime} 23.40^{\prime \prime} \mathrm{N}\right.$; $55^{\circ} 19^{\prime} 05.75^{\prime \prime} \mathrm{E}$ ). The parasites in numbers of $1,2,5$ and 8 were removed from the host and adult specimens ${ }^{1}$ were placed in normal saline on a slide to study the postovarian complex and the eggs in the terminal part of the uterus. Later, they were fixed in $70 \%$ hot $\left(70{ }^{\circ} \mathrm{C}\right)$ ethanol, stained in an aquatic solution of carmine, dehydrated increasing ethanol series, cleared in clove oil and mounted in DPX mounting medium on slides. The description is based on 4 adult specimens with the uterus containing eggs with occulate miracidia as well as free miracidia. brackets.

Measurements in micrometers (unless otherwise stated) were given as means followed by range in

\section{Cloacitrema dubaiensis Schuster, sp. n. (fig. 1-4)}

Type material: Type. Holotype and 2 paratypes deposited at Meguro Parasitological Museum as: M. P. M. Collection Number 20867

Description. Body elongate ellipsoid in shape, $3.28(3.03-3.80) \mathrm{mm}$ long by 1.15 $(1.10-1.20) \mathrm{mm}$ at greatest width. Cuticule smooth, aspinose. Oral sucker subterminal, $323(300-370) \times 468(400-500)$. Short prepharynx. Pharynx spherical $318(320-370) \times$ 370 (300-350). Esophagus short: 38 (30-50) long and 125 (100-150) wide. Caeca ending posterior to testes. Acetabulum equatorial, round: $713(650-800) \times 723(650-800)$. Testes juxtaposed or slightly oblique, close together or touching, unlobed, oval in shape, $248(200-300) \times 185(150-250)$, at posterior part of the body, intercaecally. Vasa efferentia unite on halfway between testes and acetabulum. Vas deferens proceeds dorsally to acetabulum alongside the metraterm with terminal part sac like enlarged and function-

1
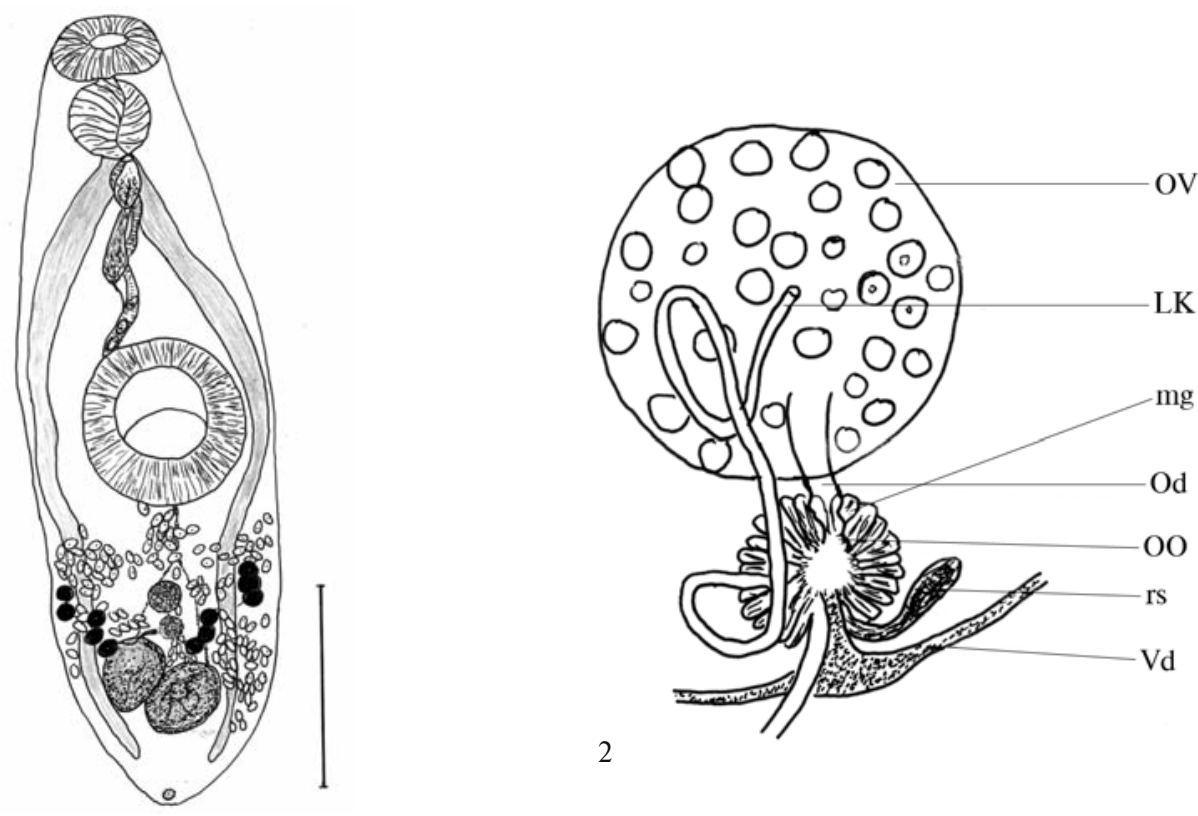

Fig. 1. Cloacitrema dubaiensis (holotype) total. Scale bar $1 \mathrm{~mm}$.

Рис. 1. Cloacitrema dubaiensis (голотип), общий вид. Масштабная линейка 1 мм.

Fig. 2. C. dubaiensis: ovary and postovarian complex. OV: ovary, LK: Laurer's canal, mg: Mehlis' gland, Od: oviduct, OO: ootype, rs: receptaculum seminis, Vd: vitelline duct.

Рис. 2. C. dubaiensis: яичник и постовариальный комплекс.

1 The most of the flukes recovered from the four birds were juvenile with undeveloped genitalia measuring only $1 \mathrm{~mm}$. 

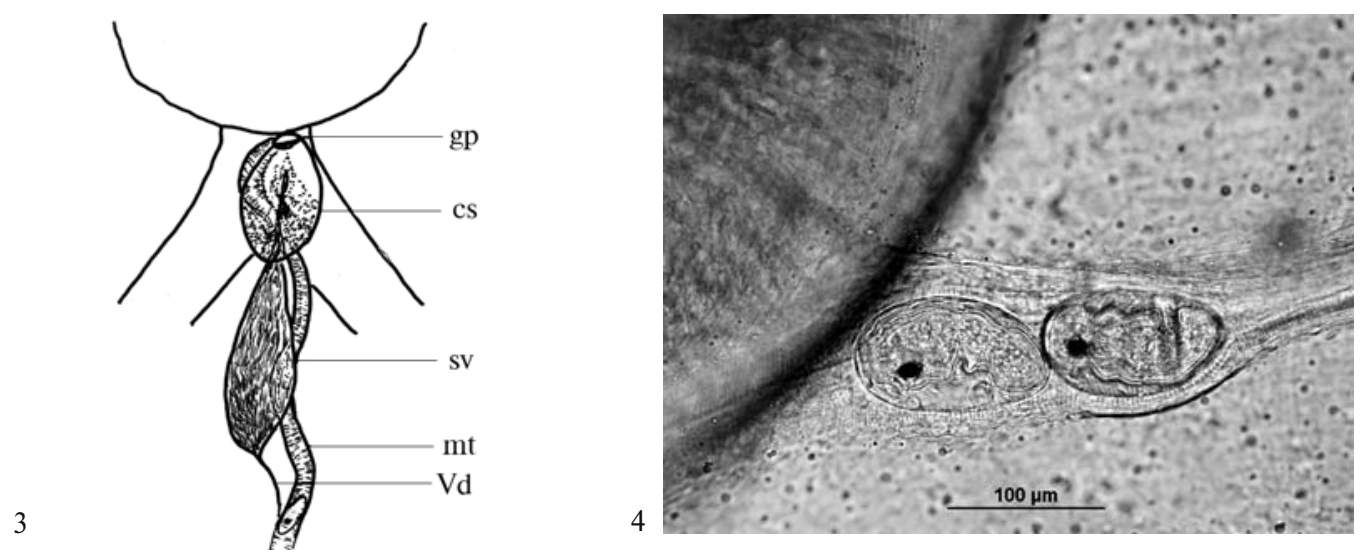

Fig. 3. C. dubaiensis: region of terminal genital ducts. gp: genital porus, cs: cirrus sac, sv: seminal vesicle, mt: metraterm, Vd: vas deference.

Рис. 3. C. dubaiensis: участок дистальных половых протоков.

Fig. 4. C. dubaiensis eggs in the metraterm.

Рис. 4. Яйца C. dubaiensis в метатерме.

ing as external seminal vesicle. Cirrus sac containing prostate cells and cirrus, terminating at a common genital pore ventral to posterior part of pharynx. Ovary spherical, median, pretesticular $160(140-200)$ in diameter. Oviduct staring at dorsal surface of ovary. Ootyp, Mehlis'gland complex, vitelline reservoir immediately posterior and dorsally to ovary. Receptaculum seminis present. Coiled Laurer's canal opens at dorsal surface at the level of ovary. Vitelline follicles compact, dorsal to caeca, 4 to 7 on each side, starting extra-caecally at the level of ovary, continuing intercaecally to anterior part of testes. Uterus posterior to acetabulum with coils reaching extracaecal space. Metraterm alongside vas deferens, dorsally of seminal vesicle and cirrus pouch and opening at common genital pore. Eggs in terminal part of uterus, in unfixed specimens yellowish, 121 $(118-125) \times 70(68-72)$ containing oculate, ciliated miracidia. Free miracidia in distal uterus elongated, 160-162 × 70-72, containing a sausage shaped sporocyste. Excretory vesicle with two arms reaching level of oral sucker, excretory pore dorsally at anterior end.

Type host: greater flamingo (Phoenicopterus roseus Pallas, 1811) (Aves, Phoenicopteridae).

Site of infection: cloaca.

Type locality: Ras al Khor, Dubai, the UAE.

Etymology: The specific epithet is derived from the locality of the host, Dubai.

\section{Differential diagnosis}

The length of Cloacitrema species varies between 1.05-1.49 $\mathrm{mm}$ in C. philippinum and 4.2-5.2 $\mathrm{mm}$ in C. oswaldoi. With an average length of 3.28 C. dubaiensis belongs to the medium sized species and is comparable only to $C$. ovatum. But with a length to width index of $2.8: 1 \mathrm{C}$. dubaiensis is the slimmest while $C$. ovatum is the broadest representative in this genus in absolute measurements as well as in relation to its length $(1.8: 1)$. C. dubaiensis has most similarities with $C$. narrabeenensis (sucker ratio of $1: 2$, uterus coils extend extracaecally, testes oval, touching, parallel to slightly oblique, presence of a cirrus, eggs more than $120 \mu \mathrm{m}$ in length and more than $60 \mu \mathrm{m}$ in width). Both species differ in body shape, the position of the acetabulum, the length of the seminal vesicle and the number of vitelline follicles and their extension lateral to caeca. 


\section{Remarks}

The main diagnostic features of the genus Cloacitrema are the position of acetabulum and testes, character of the male terminal genital ducts and the extension of uterine loops (Yamaguti, 1935). This diagnosis was extended by including the shape of the body and by the extension of vitellary fields laterally to caeca of by Kanev et al. (2005) (table 1). As seen from the table 2, only the existence of an external seminal vesicle is a common feature for all described so far Cloacitrema species. C. ovatum meets all the generic criteria while $C$. deltoidea showed the least compliance with the generic diagnosis. The description of the latter species is based on only two specimens and is most probably a result of poor fixation. $C$. deltoidea has never been mentioned again in the literature and should be treated as species inquirenda.

The postequatorial position of the ventral sucker is only the case in C. ovatum, C. pharyngeatum and $C$. marilae while the center of the acetabulum in the remaining Cloacitrema species is situated, similar to Pygorchis species, in equatorial or even pre-equatorial position.

With the exception of $C$. marilae that possesses lobed testes, in all remaining species of this genus the margin of testes is smooth. The position of testes to each other even within one species may vary from parallel to slightly oblique ( $C$. philippinum, $C$. narrabeenensis, $C$. dubaiensis). The same testes configuration is described for $P$. alacolensis and $P$. americanus while in $P$. affixus the testes are in a parallel position.

A symmetrical constriction at the level of acetabulum is only mentioned explicitly in the verbal description of $C$. ovatum and $C$. narrabeenensis. It is faintly recognizable in the figures provided in the description of $C$. oswaldoi and $C$. michiganensis and absent in C. marilae, C. philippinum and C. dubaiensis. However, such a constriction is distinct in P. americanus.

Table 1. Differentiation between Cloacitrema and Pygorchis (Kanev et al., 2005)

Таблица 1. Отличия между Cloacitrema и Pygorchis (Kanev et al., 2005)

\begin{tabular}{lcc}
\hline \multicolumn{1}{c}{ Diagnostic features } & Cloacitrema & Pygorchis \\
\hline body shape & elongate, rounded ends & elliptical ovate \\
constriction at level of acetabulum & present & - \\
center of acetabulum & postequatorial & preequatorial \\
testes & juxtaposed & diagonal \\
external seminal vesicle & present & absent \\
internal seminal vesicle & absent & present \\
vitteline follicles & inter and extracaecal & intercaecal \\
uterine loops & intercaecal & overlapping caeca \\
\hline
\end{tabular}

Table 2. Cloacitrema species that meet the diagnosic criteria of the genus Таблица 2. Виды Cloacitrema, соответствующие диагностическим критериям рода

\begin{tabular}{|c|c|c|c|c|c|c|c|c|c|}
\hline \multirow{2}{*}{ Criteria } & \multicolumn{9}{|c|}{ Species } \\
\hline & 1 & 2 & 3 & 4 & 5 & 6 & 7 & 8 & 9 \\
\hline body elongated with rounded ends & + & + & + & - & + & + & + & + & + \\
\hline symmetrical constriction at level of acetabulum & + & + & + & - & - & - & + & - & - \\
\hline acetabulum in postequatorial position & + & - & - & - & + & + & - & - & - \\
\hline testes juxtaposed, oval and smooth & + & + & + & - & - & + & \pm & \pm & \pm \\
\hline external seminal vesicle & + & + & + & + & + & + & + & + & + \\
\hline vitelline follicles extending obliquely across caeca & + & - & + & + & + & - & - & - & + \\
\hline $\begin{array}{l}\text { uterine loops pretesticular, not extending } \\
\text { laterally to caeca }\end{array}$ & + & - & - & - & + & - & - & + & - \\
\hline
\end{tabular}

Notes. $1-$ C. ovatum, $2-$ C. michiganensis, $3-$ C. oswaldoi, $4-$ C. deltoidea, $5-$ C. marilae, $6-$ pharyngeata, $7-$ C. narrabeenensis, $8-$ C. philippinum, $9-$ C. dubaiensis 
In five Cloacitrema species, vitelline follicle fields cross the caeca. In the four remaining species they are intercaecal, just reaching the dorsal surface of the caeca. Vitelline fields extending extracaecally can be seen in $P$. alacolensis and $P$. americanus but not in the type species, $P$. affixus.

The last diagnostic criterion is the intercaecal, pretesticular position of uterus coils. Only $C$. ovatum, C. marilae and $C$. philippinum fulfill this character while other Cloacitrema species do not. The uterus in all three Pygorchis species fills the postacetabular space and well extends extracaecally and posttesticular.

All but one ( $C$. pharyngeata) Cloacitrema species have eggs containing fully developed oculate miracidia. According to the egg size they can be grouped into 3 categories: 1. Small eggs with a length of less than $60 \mu \mathrm{m}$ (C. ovatum, C. pharyngeata, $C$. philippinum), 2. Medium sized eggs with a lengths between 60 and $90 \mu \mathrm{m}(C$. michiganensis, $C$. oswaldoi, C. deltoidea, C. marilae), and 3. Large eggs with a length of more than $90 \mu \mathrm{m}$ (C. narrabeenensis, C. dubaiensis). All 3 Pygorchis species have medium sized eggs.

As seen from this analysis the structure of the terminal male genital ducts is the only true character to distinguish between Cloacitrema and Pygorchis.

My thanks go to Dr. V. Besprozvannykh, Russian Academy of Science, Vladivostock, Dr. R. Salamatin, Medical University Warsaw and Dr. K. Ogawa, Meguro Parasitological Museum, Tokyo for the supply with literature sources that are difficult to access.

\section{References}

Belopol'skaja M. M. Helminth fauna of sandpipers in the lower region of the Amur in the period of flight and nidification // Trudy Gel'mint. Lab. Akad. Nauk SSSR. - 1963. - 13. - P. 164-195. - Russian : Белопольская M. М. Гельминтофауна куликов низовья Амура в период гнездования и перелета.

Cimbaluk A. K., Leonov V. A. Two new trematode species of diving ducks // Trudy Gel'mint. Lab. Akad. Nauk SSSR. - 1963. - 13. - P. 216-219. - Russian : Цымбалюк А. К., Леонов В. А. Два новых вида трематод у нырковых уток.

Howell M. J., Bearup A. J. The life history of two bird trematodes of the family Philophthalmidae // Proc. Linn. Soc. New South Wales. - 1967. - 92. - P. 182-194

Dronen N. O. Digenic trematodes from the roseate spoonbill, Ajaia ajaja, from the Texas gulfcoast // Trans. Am. Microsc. Soc. - 1985. - 104. - P. 261-266.

Kanev I., Radev V., Fried B. Family Philophthalmidae Looss, 1899 // Keys to the trematoda / Eds A. Jones, A. Bray, I. Gibson. - London : CABI Publishing and The Natural History Museum, 2005. - Vol. 2. P. 87-97.

Looss A. Weitere Beiträge zur Kenntnis der Trematodenfauna Aegyptens zugleich versuch einer natürlichen Gliederung des Genus Distomum Retzius // Zool. Jahrb. Abt. Syst. Geogr. Biol. Tiere. - 1899. - 12. P. 521-784.

Mamaev Ju. L. New species of helminthes of birds of Eastern Siberia // Trudy Gel'mint. Lab. Akad. Nauk SSSR. - 1959. - 9. - P. 175-187. - Rusian : Мамаев Ю. Л. Новые виды гельминтов от птиц Восточной Сибири.

McIntosh A. A. New philophthalmid trematode of the spotted sandpiper from Michigan and of the black-necked stilt from Florida // Proc. Helminthol. Soc. Wash. - 1938. - 5. - P. 46-47.

Travassos L. Sobre uma nova especiedo genero Cloacitrema Yamaguti, 1935 parasito de Nyctanassa violacea (L.) // Arch. Inst. Biol. S. Paulo. - 1940. - 11. - P. 589-591.

Velasquez C. C. Life cycle of Cloacitrema philippinum sp. n. (Trematoda: Digenea: Philophthalmidae) // J. Parasitol. - 1969. - 55. - P. 540-543.

Yamaguti S. Studies of the helminth fauna of Japan. Part 5. Trematodes of birds III // Jap. J. Zool. - 1935. 6. - P. 159-182.

Žatkanbaeva D. Pygorchis alakolensis sp. nov. - a new trematode found in fisheating birds of Kazakhstan (in Russian) // Izv. Akad. Nauk KazSSR. Ser. Biol. - 1967. - 5. - P. 60-62.

Received 3 September 2012

Accepted 21 November 2012 